\title{
Assessing Genetic Diversity for Yield and Quality Traits in Germplasm Lines of Bread Wheat (Triticum aestivum L.)
}

\author{
Vatsa Mishra* and Pooran Chand \\ Department of Genetics and Plant Breeding, Sardar Vallabhbhai Patel University of \\ Agriculture and Technology, Meerut- 250110, U.P., India \\ *Corresponding author
}

\section{A B S T R A C T}

\begin{tabular}{|c|}
\hline Keywords \\
\hline $\begin{array}{l}\text { Germplasm, bread } \\
\text { wheat (Triticum } \\
\text { aestivum L.) }\end{array}$ \\
\hline Article Info \\
\hline $\begin{array}{l}\text { Accepted: } \\
\text { 20 January } 2018 \\
\text { Available Online: } \\
\text { 10 February } 2018\end{array}$ \\
\hline
\end{tabular}

\section{Introduction}

Wheat (Triticum aestivum L.) is a selfpollinated crop of the Poaceae family and the world's largest famous energy rich cereal crop. India stands second rank in production and consumption and both next to China in the world. India's share in world wheat production is about $14.13 \%$ of world's wheat production. Wheat is the only crop where in production increase is more than fifteen fold during last sixty three years (6.5 million tons in 1950 to 95.87 million tons in 2014 (Anonymous; 2014). Wheat is the first important and strategic cereal crop for the
Fifty germplasm of bread wheat used to study the nature and magnitude of genetic divergence using Mahalanobis's $\mathrm{D}^{2}$ statistics. The data for twelve important quantitative traits recorded from the genotypes raised in Randomized Block Design having three replications. The fifty genotypes were grouped into eight clusters. Cluster I was largest with fourteen genotypes followed by cluster IV with ten genotypes. The maximum intercluster distance was observed between cluster II and III, suggesting that the genetic clusters. Noteworthy is that cluster IV exhibited high cluster means for days to $50 \%$ flowering; cluster VIII for plant height and cluster VI for spike length. Among the twelve traits studied, maximum contribution was made by number of effective tillers per plant contributed maximum divergence $(12.84 \%)$ followed by number of spikelets per spike (11.24\%), length of spike (11.05\%), biological yield per plant (10.15\%). Therefore, these characters may be given importance during hybridization program. 
day bread wheat varieties produce and close relatives may be divided into diploid, tetraploid and hexaploid species with chromosome number $2 \mathrm{n}=14=\mathrm{AA}, 2 \mathrm{n}=14=$ $\mathrm{BB}, 2 \mathrm{n}=28=\mathrm{AABB}$ and $2 \mathrm{n}=42=$ AABBDD respectively with basic chromosome number $(\mathrm{x})=7$ (Sleper and Phoelman, 2006). However, DNA analysis revealed a wild diploid Triticum urartu, instead of Triticum monococcum, as donor of A genome (Dvorak et al., 1993) and a wild diploid Aegilops speltoides as possible donor of B genome (Kilian et al., 2007). D ${ }^{2}$-statistic as multivariate analysis is a powerful tool in the in estimating genetic divergence in crop plants. Being a numerical estimate this method has an added advantage over other as it permits precise comparisons among all possible traits of population in a group and its commutation offers the automatic removal of the effects of correlations among the genetic variables involved to its efficiencies and usages.

The utility of Mahalanobis's generalized distance $\left(D^{2}\right)$ is not only limiting factor for determining the degree of divergence in different populations but also for selecting genetically diverse parents for an efficient breeding program.

\section{Materials and Methods}

A total of 50 genotypes of wheat collected from Department of Genetics and Plant Breeding, SVPUAT, MEERUT taken for divergence study (Table 1). The present investigations were carried out in 2015-16 at APEDA Farm, Meerut in RBD manner with three replications.

Each genotype was sown in three rows plot of 4 meter length spaced $22.5 \mathrm{~cm}$ apart with plant to plant distance of $10 \mathrm{~cm}$. All the recommended cultural practices were followed under irrigated conditions as and when needed. The observations were recorded on five random competitive plants per replication for each genotype on nine important characters i.e. days to $50 \%$ flowering, days to maturity, plant height, length of spike, number of effective tillers, number of spikelets per spike, number of grains per spike, 1000 seed weight, biological yield per plant, harvest index, gluten content in order to study the magnitude of genetic divergence in germplasm. The Mahalanobis $\mathrm{D}^{2}$ (1936) statistic was used to quantify genetic diversity among the genotypes. The $\mathrm{D}^{2}$ values were used to classify the entire germplasm into distinct clusters, which was done following to Tocher's method [Rao (1952)].

\section{Results and Discussion}

Analysis of variance revealed significant differences among the genotypes of wheat for all the quantitative traits, indicating the considerable amount of variability. Following Tocher's cluster analysis 50 genotypes were grouped into eight clusters, revealing the presence of diversity for different growth and flowering traits (Table 1). It was observed that Cluster I has maximum (14) genotypes followed by cluster IV has (10) genotypes, cluster V, VI and VII each have seven genotypes, cluster III has three genotypes and cluster II and VIII has one genotype each.

The genotypes within a cluster have smaller $\mathrm{D}^{2}$ values among themselves than those belonging to different clusters. The genotypes from distinct clusters are genetically diverse in nature, which can be utilized in the crop improvement program for various commercial traits.

The maximum intra cluster distance was recorded for cluster VII (2.604), followed by cluster III (2.520), cluster I (2.479), cluster VI (2.231), cluster IV (2.222), cluster V (2.071), cluster II (0.985) and cluster VIII (0.003) (Table 2). 
Table.1 Distribution of fifty genotypes of wheat

\begin{tabular}{|c|c|c|c|}
\hline S. No. & Clusters & $\begin{array}{l}\text { Number of } \\
\text { genotypes }\end{array}$ & Genotype Name \\
\hline 1. & I & 14 & $\begin{array}{l}\text { PBW226, K6525, K9162, PBW 435, WH 1021, DBW 72, } \\
\text { RAJ 3765, HD 3076, K 8962, HD 2733, K 607, K 452, DBW } \\
\text { 16, HD 2985. }\end{array}$ \\
\hline 2. & II & 1 & K 424 \\
\hline 3. & III & 3 & RAJ 4246, W1105, MP 3336 \\
\hline 4. & IV & 10 & $\begin{array}{l}\text { PBW } 373, \text { K 402, HD 2285, HUW 658, PBW 343, WCW } \\
\text { 985, W 1129, WH 841, HD 3068, AAI } 16\end{array}$ \\
\hline 5. & $\mathrm{~V}$ & 7 & LN 121, PBW 550, PBW 590, K 802, PBW 502, K 1250 \\
\hline 6. & VI & 7 & $\begin{array}{l}\text { UNNAT HALNA, HD 3095, PBW 533,UP 2792, K 9533, K } \\
9107\end{array}$ \\
\hline 7. & VII & 7 & K 906, PBW 39, MP 4010, K 616, K9423, K 991 \\
\hline 8. & VIII & 1 & K 9265 \\
\hline \multicolumn{2}{|c|}{ Total } & 50 & \\
\hline
\end{tabular}

Table.2 Average intra and inter cluster ( $\mathrm{D}^{2}$ value) distance in 50 genotypes of wheat

\begin{tabular}{|c|c|c|c|c|c|c|c|c|}
\hline Clusters & I & II & III & IV & V & VI & VII & VIII \\
\hline I & $\mathbf{2 . 4 7 9}$ & & & & & & & \\
\hline II & 7.247 & $\mathbf{0 . 9 8 5}$ & & & & & & \\
\hline III & 4.180 & 9.599 & $\mathbf{2 . 5 2 0}$ & & & & \\
\hline IV & 2.584 & 7.766 & 5.619 & $\mathbf{2 . 2 2 2}$ & & & & \\
\hline V & 2.234 & 7.049 & 4.037 & 3.207 & $\mathbf{2 . 0 7 1}$ & & & \\
\hline VI & 3.208 & 8.136 & 4.793 & 3.234 & 3.014 & $\mathbf{2 . 2 3 1}$ & & \\
\hline VII & 3.783 & 7.107 & 6.025 & 4.331 & 3.278 & 4.387 & $\mathbf{2 . 6 0 4}$ & \\
\hline VIII & $\mathbf{5 . 2 1 0}$ & $\mathbf{8 . 3 1 9}$ & $\mathbf{7 . 2 3 3}$ & $\mathbf{5 . 1 6 5}$ & $\mathbf{5 . 0 6 2}$ & $\mathbf{5 . 6 6 7}$ & $\mathbf{5 . 6 6 7}$ & 0.003 \\
\hline
\end{tabular}

Table.3 Cluster mean values for twelve characters in wheat

\begin{tabular}{|c|c|c|c|c|c|c|c|c|c|c|c|c|}
\hline $\begin{array}{r}\text { Charact } \\
\text { er }\end{array}$ & $\begin{array}{l}\text { Days } \\
\text { to } \\
50 \% \\
\text { flower } \\
\text { ing }\end{array}$ & $\begin{array}{l}\text { Days to } \\
\text { maturity }\end{array}$ & $\begin{array}{c}\text { Plant } \\
\text { height } \\
(\mathrm{cm})\end{array}$ & $\begin{array}{l}\text { Length } \\
\text { of } \\
\text { spike } \\
\text { (cm) }\end{array}$ & $\begin{array}{l}\text { Effecti } \\
\text { ve } \\
\text { tillers }\end{array}$ & $\begin{array}{c}\text { No of } \\
\text { spikele } \\
\text { ts/ } \\
\text { spike }\end{array}$ & $\begin{array}{c}\text { No. Of } \\
\text { grains/ } \\
\text { spike }\end{array}$ & $\begin{array}{c}1000 \\
\text { grain } \\
(w t)\end{array}$ & $\begin{array}{l}\text { Biologi } \\
\text { cal } \\
\text { yield } \\
\text { (g/plan } \\
\text { t) }\end{array}$ & $\begin{array}{c}\text { Grain } \\
\text { yield/p } \\
\text { lant }\end{array}$ & HI (\%) & $\begin{array}{c}\text { Gluten } \\
\text { conten } \\
\mathbf{t}\end{array}$ \\
\hline I & 79.98 & 127.52 & 85.45 & 10.06 & 9.12 & 16.64 & 44.87 & 38.15 & 42.86 & 16.71 & 38.62 & 7.86 \\
\hline II & 79.67 & 79.67 & 95.00 & 9.56 & 8.05 & 13.67 & 37.51 & 43.34 & 46.00 & 14.52 & 30.26 & 7.69 \\
\hline III & 79.11 & 124.00 & 84.62 & 10.18 & 9.70 & 19.74 & 56.39 & 37.31 & 46.44 & 20.11 & 44.08 & 8.31 \\
\hline IV & 82.47 & 131.23 & 77.67 & 8.32 & 8.02 & 16.64 & 43.98 & 38.71 & 38.91 & 15.36 & 38.65 & 8.07 \\
\hline$\overline{\mathbf{V}}$ & 76.52 & 122.38 & 88.03 & 9.10 & 8.77 & 17.60 & 47.85 & 39.63 & 43.18 & 16.32 & 38.10 & 8.45 \\
\hline VI & 81.00 & 127.52 & 85.34 & 10.49 & 7.34 & 18.67 & 50.10 & 37.01 & 40.44 & 15.11 & 37.06 & 8.73 \\
\hline VII & 77.62 & 124.95 & 92.57 & 8.41 & 8.72 & 15.85 & 44.07 & 35.17 & 51.65 & 15.74 & 30.53 & 8.82 \\
\hline VIII & 81.00 & 130.00 & 127.63 & 7.67 & 7.77 & 16.25 & 43.26 & 39.55 & 37.54 & 15.63 & 41.54 & 8.18 \\
\hline
\end{tabular}


Table.4 Contribution of different characters in creating diversity in wheat based on Mahalanobis's $\mathrm{D}^{2}$ analysis

\begin{tabular}{|c|l|c|}
\hline S. No. & \multicolumn{1}{|c|}{ Character } & Contribution \% \\
\hline 1 & Days to 50\% flowering & $4.77 \%$ \\
\hline 2 & Days to maturity & $8.86 \%$ \\
\hline 3 & Plant height(cm) & $29.60 \%$ \\
\hline 4 & Length of spike (cm) & $12.53 \%$ \\
\hline 5 & No. of effective tillers/plant & $7.70 \%$ \\
\hline 6 & No. of spikelets/spike & $6.55 \%$ \\
\hline 7 & Biological yield/plant (g) & $5.82 \%$ \\
\hline $\mathbf{8}$ & Harvest index (\%) & $2.95 \%$ \\
\hline $\mathbf{9}$ & No. of grains/spike & $4.02 \%$ \\
\hline 10 & 1000 grain weight(gm) & $4.07 \%$ \\
\hline 11 & Grain yield /plant (g) & $6.01 \%$ \\
\hline 12 & Gluten content & $7.06 \%$ \\
\hline
\end{tabular}

Maximum inter cluster $\mathrm{D}^{2}$-value (9.599) was observed between cluster II and cluster III followed by cluster II and VIII (8.319), indicating wide diversity between the cultivars of these groups, cluster II and VI (8.136), cluster II and IV (7.766), cluster I and II (7.242), cluster III and VIII (7.333) and between cluster III and VII (6.025) whereas, the minimum average inter cluster $\mathrm{D}^{2}$ value (2.234) was recorded between cluster I and V. The maximum inter cluster $\mathrm{D}^{2}$-value indicated that genotypes of cluster II and III are not so closely related whereas, the minimum inter cluster distance indicated that the genotypes of these clusters are closely related. The genotypes of cluster I and V showed minimum inter cluster distance (2.234) so these genotypes are closely related. The genotype from individual cluster can be utilized in the selection/breeding program for desirable economic characters in wheat. The cluster mean calculated for 12 characters under study are presented in Table 3. Days to $50 \%$ flowering exhibited maximum mean in cluster IV (82.47). The mean of days to maturity was observed maximum (131.23) in cluster IV. Plant height showed highest mean for cluster number VIII (127.63). Cluster number VI exhibited maximum mean (10.49) for spike length. Number of effective tillers per plant showed highest mean (9.70), (19.74) for number of spikelets per spike for cluster III. Cluster number III, showed maximum mean value (19.74) for number of spikelets per spike. For biological yield per plant, cluster VII showed maximum (51.65) mean values. For harvest index (\%), cluster number III exhibited maximum mean value (44.08). For number of grains per spike, highest mean value (56.39) was noted in cluster number III. The highest mean value for 1000-grain weight was exhibited by the cluster number II (43.34). The highest mean value for grain yield was exhibited by the cluster number III (20.11).Gluten content reflected maximum mean in cluster VII (8.82). Therefore, based on $\mathrm{D}^{2}$ analysis it has been understood that, different genotypes had significant effect on the clustering pattern, the characters contributing for divergence and cluster means, hence these characters need to be given more weightage, while selecting parents for crop improvement Singh and Upadhyay (2013), Sabaghnia et al., (2014), Sharma et al., (2015), Ramakrishnan S. et al., (2016). The per cent contribution of each character 
was ranked on the basis of per cent contribution to that character. The number of effective tillers per plant contributed maximum divergence $(12.84 \%)$ followed by number of spikelets per spike (11.24\%), length of spike (11.05\%), biological yield per plant $(10.15 \%)$, 1000-grain weight $(8.80 \%)$, grain yield per plant $(8.56 \%)$, days to $50 \%$ flowering $(8.35 \%)$, plant height $(7.55 \%)$, gluten content $(7.26 \%)$, days to maturity (5.47\%), harvest index (4.82\%) and minimum divergence was contributed by number of grains per spike $(3.90 \%)$. These results are somewhat in accordance with the findings of Singh et al., (2002), Singh and Dwivedi (2005), Dobariya et al., (2006), Mittal et al., (2008) and Peshattiwar et al., (2009) (Table 4).

The success of breeding program depends upon the genetic diversity present among the parents. Divergence has to be studied in different environments in the breeding varieties and crosses between the genotypes of divergent clusters may be tried for crop improvement.

\section{References}

Dobariya, K.L., Ribadia, K.H., Padhar, P.R. and Ponkia, H.P. (2006). Analysis of genetic divergence in some synthetic lines of bread wheat (Triticum aestivum L.). Advances in Plant Sciences. 19(1): 221- 225.

Kilian, B., Ozkan, H., Deusch, O., Effgen, S., Brandolini, A., Kohl, J., Martin, W. and Salamini, F. (2007). Independent wheat
$B$ and $G$ genome origins in outcrossing Aegilops Progenitor Haplotypes. Mol. Biol. Evol. 24(1): 217227.

Mahalanobis, P. C. (1936). On the generalized distance in statistics. Proc Nat Inst Sci India 2: 67- 70.

Mittal, V.P. and Brar, K. S. (2008). Divergence analysis for some yield contributing characters in wheat (Triticum aestivum L.). Crop Improvement, 35(1): 1-3.

Peshattiwar, P.D., Ghorpade, P.B., Dandge, M.S., Thorat, Archana and Gomase, D.G. (2009). Genetic divergence in duram wheat cultivars. International Journal of Agricultural Sciences, 5(1): 243-247.

Ramakrishnan, S. (2016). Multivariate analysis for stay green and some metric traits in wheat (Triticum aestivum L.). Indian Agricultural Research Institute, New Delhi. 34 (3A): 1104-1108.

Rao, C. R. (1952). Advanced statistical methods in Biometric Research. Edn. John Willey and Sons Inc. New York $\mathrm{Pp}$

390.

http://krishikosh.egranth.ac.in/bitstream /1/2028614 / 1 / 23037.pdf

Singh, Bhuri and Upadhyay, P.K. (2013). Genetic divergence analysis in wheat (Triticum aestivum L.). Internat. J. Plant Sci., 8(2): 297-299.

Singh, S.P. and Dwivedi, V.K. (2002). Genetic divergence in bread wheat. New Agriculturist, 13(7): 2-7.

\section{How to cite this article:}

Vatsa Mishra and Pooran Chand. 2018. Assessing Genetic Diversity for Yield and Quality Traits in Germplasm Lines of Bread Wheat (Triticum aestivum L.). Int.J.Curr.Microbiol.App.Sci. 7(02): 2281-2285. doi: https://doi.org/10.20546/ijcmas.2018.702.275 